ISSN: 0213-2052 - eISSN: 2530-4100

DOI: https://doi.org/10.14201/shha202038273307

\title{
LA CONDENA LEGAL \\ DE LA HOMOSEXUALIDAD MASCULINA \\ EN EL REINO VISIGODO DE TOLEDO
}

\section{The Legal Conviction of Male Homosexuality in the Visigothic Kingdom of Toledo}

\author{
Rosario VALVERDE CASTRO \\ Universidad de Salamanca \\ charoval@usal.es
}

Fecha de recepción: 16-07-2019; aceptación definitiva: 22-03-2020

ORCID: https://orcid.org/0000-0002-8984-8408

RESUMEN: El objetivo de este trabajo es analizar las disposiciones contra la homosexualidad masculina, excepcionales en el entorno occidental del siglo vis, que vieron la luz en el reino visigodo de Toledo. A instancias regias, se promulgaron dos leyes y una norma conciliar, en las que se penalizó, con extrema severidad, que los hombres mantuvieran relaciones sexuales entre sí. Iniciamos su estudio con un apartado introductorio donde tratamos de desvelar cómo se fueron imponiendo, en la Roma imperial, las corrientes de pensamiento que reprobaron las relaciones carnales entre personas del mismo sexo. Al volverse predominantes en la Antigüedad tardía, del oprobio, se pasó a la condena de la homosexualidad.

Palabras clave: Homosexualidad; visigodos; Reino de Toledo; Liber Iudiciorum; Antigüedad tardía.

ABSTRACT: The objective of this work is to analyze the provisions against male homosexuality, uncommon in 7 th century Western society, which came to light in the Visigothic kingdom of Toledo. Following royal 
orders, two laws and a conciliatory ruling were enacted in which men were severely punished for having sexual relations with other men. We began our study by providing an introductory section where we attempt to reveal how schools of thought, in Imperial Rome, were imposed condemning same-sex carnal relations. Although a more common practice during Late Antiquity, homosexual sex became disgraceful and was condemned.

Keywords: Homosexuality; Visigoths; Kingdom of Toledo; Liber Indiciorum; Late Antiquity.

\section{A modo de introducción: De la permisividad de la antigua Roma}

AL RIGORISMO SEXUAL DE LA ANTIGÜEDAD TARDía

En la mentalidad imperante en el reino visigodo de Toledo, no se valoraban como positivos los placeres de la carne. El ideal de castidad primaba sobre el disfrute del cuerpo y las únicas relaciones sexuales consentidas eran las que tenían lugar en el seno del matrimonio, buscando la procreación como único fin. En consonancia con estos principios éticos, practicar sexo entre hombres fue considerado un acto abominable que había que combatir y, en efecto, acabó siendo duramente penalizado en la normativa legislativa y conciliar de la segunda mitad del siglo vII.

En la represión legal de las relaciones carnales entre hombres subyace una percepción negativa de la sexualidad humana que, en el caso del reino visigodo hispano, puede ser vista como un legado de los principios rectores en el Imperio romano tardío. Se tendió entonces a denostar el deseo sexual y, como consecuencia, fue progresivamente esfumándose la indiferencia hacia las relaciones homosexuales en el terreno legislativo, que había caracterizado al periodo republicano y a los primeros tiempos imperiales, una indiferencia normativa que se había traducido en un alto grado de permisividad en asuntos sexuales.

En esas etapas más antiguas, que un hombre se sintiese atraído sexualmente por otro hombre no era ni causa de oprobio social o moral, ni materia particular del derecho. Era simplemente una opción posible. Como ha afirmado Eva Cantarella ${ }^{1}$,

La homosexualidad no era una elección exclusiva [...]. Era solamente una parte de la experiencia vital: era la manifestación de una pulsión sea sentimental, sea sexual que a lo largo de la existencia se alternaba y complementaba [...] con el amor por una mujer.

1. [1988] 1991, 9. 
Por lo tanto, las categorías de "heterosexual" y "homosexual", tal y como hoy en día las entendemos, es decir, como términos que aluden a la atracción, única y excluyente, que puede sentirse por personas de distinto o del mismo género, aún no existían en la antigua mentalidad romana ${ }^{2}$. Además, sentirse atraído por otro hombre no estaba fuera de la norma. No era el sexo de la persona objeto del deseo lo que determinaba las restricciones en materia sexual, por lo que la homosexualidad, per se, no es que no fuera una práctica denostada, es que ni siquiera era tomada en consideración. Como ha defendido Paul Veyne, el amor físico estaba regido por la existencia de una moralidad diferente para hombres y mujeres, para cada edad y para cada grupo social, dando lugar a que algunos de los prejuicios vigentes en materia sexual tuvieran que ver con el rol, activo o pasivo, que una persona desempeñaba cuando copulaba. Ser pasivo, dejarse penetrar por el amante, era propio de mujeres, de muchachos y de esclavos. Reflejaba debilidad y, por lo tanto, era una actitud duramente reprobada. Un ciudadano libre tenía que dominar. Por respeto a su estatus social, no podía rebajarse y adoptar un comportamiento propio de inferiores. Lo que estaba en juego, siempre en opinión de Paul Veyne, era tomar el placer virilmente o darse servilmente, no sentirse atraído por uno u otro género ${ }^{3}$.

Esa distinción entre comportamientos sexuales considerados lícitos o ilícitos en función del género, la edad o el grupo social al que se perteneciera, tendió a esfumarse con el paso del tiempo y la nueva ética sexual general, igual para todos, que progresivamente fue imponiéndose en el mundo romano, resultó ser mucho más represiva con los actos encaminados a expresar cualquier tipo de pasión erótica. Hacia el siglo iv, ya era perceptible que, si no todos, al menos los más importantes sistemas filosóficos del paganismo se habían vuelto más intolerantes con el placer sexual. En líneas generales, coincidieron en ensalzar el control de la parte instintiva del ser humano, por considerarla impura, y en elevar

2. Como muestra Féray 1981, 11-21, la acuñación del término «homosexualidad» se suele atribuir a Karld Maria Kertbeny, quien, en 1869, parece que lo empleó en unos panfletos anónimos en los que abogaba por la revocación de la ley contra la sodomía contenida en el código penal prusiano. No obstante, y a pesar de la enorme distancia temporal existente entre la aparición del concepto y la época que es objeto de nuestro estudio, utilizaremos el término y sus derivados para facilitar tanto la propia redacción del texto, como la comprensión del mismo.

3. Veyne 1982, 26-33. Sobre la percepción de la homosexualidad en la antigua Roma, también pueden verse: Boswell [1980] 1993, 84-11; Brundage [1987] 2000, 41-61; Brown [1988] 1993, 54-55; Cantarella [1988] 1991, 131-212; Williams 1999, especialmente a partir de la p. 125 . 
la abstinencia sexual a la categoría de virtud, lo que llevó a denostar el coito no procreativo, en particular si se realizaba fuera del matrimonio ${ }^{4}$. El mismo tipo de transformación se operó en las corrientes de pensamiento dominantes en el cristianismo. Aunque parece ser que ni a Jesús ni a sus primeros seguidores les preocupó en exceso el tema de las relaciones sexuales 5 , a partir de Pablo, quien ya condenó todo comportamiento homosexual, tanto el pasivo, como el activo ${ }^{6}$, es decir, desde el siglo i d. C., comienza a manifestarse la característica obsesión por la castidad de la religión cristiana. Dicha obsesión fue acentuándose con el paso del tiempo y, como es de sobra conocido, cuando en el siglo iv se adoptó el cristianismo como religión oficial del Estado romano, la mayor parte de la intelectualidad cristiana concebía el cuerpo humano como

un "templo sacrosanto" -afirma Peter Brown-, que Dios había destinado a acoplarse, si acaso, exclusivamente con personas del sexo contrario y, por lo tanto, idealmente, únicamente para engendrar hijos?

En este contexto general de repudio de cualquier tipo de relación sexual que buscase el mero disfrute corporal, la homosexualidad estaba inexorablemente abocada a ser rechazada y perseguida. En el caso de las relaciones carnales entre personas del mismo sexo, no se daban ninguna de las condiciones exigidas por las nuevas concepciones éticas para volver aceptable una experiencia sexual porque, como es evidente, ni la cópula tenía lugar dentro del matrimonio ni el fin que perseguía era la procreación. Se discute si la religión cristiana, asumiendo el repudio judío del sexo entre hombres, fue la responsable de la demonización de la homosexualidad o si, por el contrario, se limitó a hacer suya la intolerancia pagana en materia sexual del Imperio tardío, siendo, eso sí, su mejor

4. Sorprendió a Foucault y Sennett 1981, 5-6, descubrir que el código de comportamiento sexual que sólo admite la «monogamy, faithfulness and procreation as the main, or maybe the single, justification of sexual acts - sexual acts wich remain, even in such conditions, intrinsically impure, y que suele considerarse propio del cristianismo, también existiese en el mundo pagano, llevándoles a afirmar que: «the so called Christian morality is nothing more than a piece of pagan ethics inserted into Christianitys. Concretando más, Boswell [1980] 1993, 155-158 y Espejo Muriel 1991, 143-150, desvelan qué corrientes del pensamiento pagano pudieron ejercer mayor influencia en el repudio cristiano del placer sexual.

5. Cfr. Boswell [1980] 1993, 139; Brundage [1987] 2000, 76.

6. Sobre la condena paulina de las prácticas homosexuales, BrundaGe [1987] 2000, 77-

79 y 87; Cantarella [1988] 1991, 246-249; Espejo Muriel 1991, p. 176.

7. Brown [1988] 1993, 586. 
difusora ${ }^{8}$. Con independencia de que se opte por una u otra interpretación, lo que resulta indiscutible es que las relaciones sexuales entre personas del mismo género fueron vilipendiadas y, del oprobio, se pasó a la persecución. La represión imperial comenzó, con seguridad, a partir del siglo Iv, con la condena, presumiblemente con la castración, de la homosexualidad pasiva. A finales de la década de los 30 del siglo siguiente, se castigó, con la muerte en la hoguera, a todos los que se dejasen penetrar en una relación carnal entre hombres y, en el siglo vi, durante el gobierno de Justiniano (527-565), se llegó a imponer la pena máxima a los dos miembros de la pareja, dejando ya de importar cuál fuera el rol ejercido por cada uno de ellos en el acto sexual'.

En el reino de Toledo, que se formó a partir del asentamiento, masivo y permanente, de los godos en la península ibérica a finales del siglo $\mathrm{v}$, principios del vi, las relaciones homosexuales masculinas suscitaron el mismo tipo de aversión que hemos visto surgir en la Roma tardo-imperial. Resulta revelador al respecto el testimonio que nos ofrece Isidoro de Sevilla en sus famosas Etymologiae, obra en la que se trató de recopilar todo el saber de la época y que fue concluida hacia el $632 / 3^{10}$. En este texto, volvemos a descubrir un fuerte desprecio por la actividad sexual, que, al ser presentada como impura, manifestación de la fragilidad humana y origen de los vicios más nefastos, debe ser reprimida a toda costa, a no ser que se oriente a asegurar una descendencia legítima. En consecuencia, todo «lo que no se ajuste al esquema cristiano de la sexualidad conyugal reproductora se considera lujuria y lascivia, por tanto, fornicación pecaminosa y engendradora de delitos», categoría en la que, por supuesto, se incluyen las prácticas homosexuales ${ }^{11}$.

No es de extrañar que, en el regnum Toletanum, encontremos una ética sexual similar a la dominante en la Roma tardía, si tenemos en cuenta que la nueva realidad de poder no solo se creó en un espacio que había pertenecido al Imperio romano, sino que surgió a partir de la llegada de unas poblaciones, a las que etiquetamos bajo el calificativo de visigodos, que se conformaron como tales, a partir de finales del siglo iv, viviendo

8. Baste citar a Cantarella [1988] 1991, 241-268, representante de la primera de las dos líneas interpretativas mencionadas, porque recoge y analiza los principales argumentos esgrimidos por los participantes en esta controversia.

9. Cantarella [1988] 1991, 236-281 y Espejo Muriel 1991, 185-197, recogen y analizan las leyes tardo-imperiales contra la homosexualidad masculina.

10. Sobre el contenido y la elaboración de las Etymologiae, CODOÑER 2010, 147-148.

11. Sintetizamos aquí parte de los aspectos analizados por Gallego Franco 2003, $407-$ 431, trabajo al que pertenece la frase reproducida en el cuerpo del texto (418). 
en territorios imperiales ${ }^{12}$. Por lo tanto, fue en contacto con esa moral pagana, ya más rigorista en materia sexual, y durante el periodo en el que el código ético represivo del cristianismo triunfante estaba imponiéndose, cuando se desarrolló la identidad del grupo humano que llamamos visigodo. En consecuencia, fue esa mentalidad restrictiva en el ámbito de las relaciones sexuales, no la aperturista de los antiguos tiempos romanos, la que ejerció sobre ellos una fuerte influencia. Además, tras su asentamiento definitivo en la península ibérica, abandonaron el arrianismo que practicaban (que, aunque ya considerado herético, también era cristianismo), y en el Concilio III de Toledo, celebrado en el 589, durante el reinado de Recaredo (586-601), se proclamó la ortodoxia nicena como la religión oficial del reino. Ya en el mismo concilio de la conversión descubrimos que se está formulando una teoría del poder, de base religiosa, centrada en la idea del origen divino de la monarquía, que no cesará de desarrollarse con el paso del tiempo ${ }^{13}$. En la nueva ideología, el deber supremo del soberano pasó a ser la dirección de la sociedad cristiana puesta a su cargo por Dios, lo que dio lugar a que se estableciese una estrecha colaboración entre el poder monárquico y las élites eclesiásticas que, entre otras cosas, persiguió imponer, en la vida cotidiana, el respeto a los principios de la moral cristiana.

En semejante contexto político, ético y religioso, en el que, como es lógico, no se distinguía con nitidez entre delitos civiles y faltas contra la divinidad, es perfectamente comprensible que se considerase infamante, y fuese objeto de persecución, el mantener relaciones carnales con personas del mismo sexo. Lo que sí puede llamar la atención, en cambio, es que la primera condena explícita de las relaciones homosexuales no viera la luz hasta mediados del siglo viI, sesenta y cinco años después de la conversión del reino. Asimismo, también puede resultar hasta cierto punto sorprendente que la represión del sexo homosexual procediera, en origen, de la autoridad monárquica, no de la religiosa, como, en principio, cabría esperar.

12. Solo a partir del 395, cuando la figura de Alarico adquirió preeminencia como caudillo godo, puede trazarse una línea de continuidad entre las poblaciones que le seguían y las que dieron lugar a los denominados reinos de Tolosa y de Toledo (c $f r$. Liebeschuetz 1992, 75-83; Heather 2004, 141-159; Díaz, Valverde 2007, 354-355.

13. Véase más adelante, p. 297, n. 68. 
2. La ley 3.5.4 De Chindasvinto: la primera norma Que CONDENó LA HOMOSEXUALIDAD MASCULINA EN EL REGNUM TOLETANUM

Es en el gran corpus legislativo que nos ha legado el reino de Toledo, hoy habitualmente conocido como Lex Visigothorum ${ }^{14}$, aunque, en su propia época, se le debió de denominar Liber Iudiciorum (en adelante, L.I. $)^{15}$, donde encontramos la primera norma de la Hispania goda en la que se prohíbe categóricamente, y se condena con contundencia, que se practique sexo entre hombres. El Liber no solo contiene leyes de Recesvinto (653-672), el rey que lo promulgó en el año 654. Recoge, además de las disposiciones dictadas por este monarca, numerosas leyes de sus predecesores $^{16}$ : las de Leovigildo (573-586) y sus antecesores suelen ser calificadas como antiquae; en todas las posteriores, es decir, a partir de las de Recaredo o, lo que es lo mismo, de la conversión del reino a la ortodoxia nicena, se consignó el nombre del rey que las había promulgado ${ }^{17}$, lo que nos permite saber que la primera norma contra las relaciones homosexuales fue emitida por Chindasvinto (642-653), el padre de Recesvinto. De hecho, la ley va precedida de la fórmula Flavius Chindasvindus rex, la sucinta, pero característica titulatura regia del regnum Toletanum, que presenta a sus soberanos como los legítimos sucesores de los emperadores romano-cristianos en Hispania ${ }^{18}$. Se trata de la L.I. 3.5.4, en la que, con

14. Es el nombre que le dio K. Zeumer en su edición de los Monumenta, pero, según Joye 2012, 95, nunca había sido utilizado antes del siglo IX.

15. Como señalan Petit 2001, 75, n. 1 y Martin 2011, 18, este es, al menos, el nombre que se le da en el manuscrito más antiguo conservado. Ambos autores reclaman el empleo de esta denominación (el primero lo hace en otro lugar, Ретіт 2007, 75-76), para evitar que el título de Lex Visigothorum sugiera que se trata de un código de aplicación personal y no territorial.

16. García López 1997, 9-10; Kelly 2017, 114-115 y 123-124 o Ramis Barceló 2015, 14 , proporcionan una descripción más detallada de las leyes que forman el Liber de Recesvinto.

17. En la distinción que se establece en la forma de identificar las leyes anteriores y posteriores a Recaredo, descubre Morales Arrizabalaga 1995, 168, la posibilidad de "que Recesvinto haya querido establecer una diferencia sustancial entre las normas que provienen de gobernantes anteriores a la conversión, que no son leyes ni derecho, porque no provienen de reyes rectos, pero pueden ser tenidas por justas a causa de su antigüedad, y las que ya provienen de reyes legitimados por la fe católica, que son identificadas por el nombre del rey que las decretó». Por su parte, Martin 2011, 19-20, sostiene que "L'effacement du nom des législateurs antérieurs à Reccared ressemble en fait plutôt à une damnatio memoriae appliquée à tous les rois gohts ariens [...] La mise en oeuvre d'un tel procédé correspond d'ores et déjà à une prise de position des compilateurs, qui établissent ainsi un distinguo entre bons et mauvais souverains».

18. Díaz y díaz 1976, 131 y 139-140; Valverde Castro 2000, 201. 
el título De masculorum stupris ("De los actos deshonestos entre hombres"), se comienza regulando lo siguiente:

Non relinquendum est scelus inultum, quod detestandum semper execrabile morum pravitate censetur. Masculorum ergo concubitores, vel qui talia consentientes pertulerint, sta sunt legis huius sententia feriendi, ut scilicet, mox tale nefas admissum iudex evidenter investigaverit, utrosque continuo castrare procuret, et tradens eos pontifici territori huius, ubi id perpetrari contigerit, sequestratim ardue mancipentur detrusioni, vel inviti saltim luituri commissa, qui voluntarie perpetrasse noscuntur inlicita. Hoc interim orrendum dedecus si inferens quisque vel patiens non voluntarius, sed invitus explesse dinoscitur, tunc a reatu poterit inmunis haberi, si nefandi buius sceleris ipse detector extiterit; ille procul dubio tenendus est ad penam, quem in hac sponte devolutum constat insaniam.

No debe dejarse sin castigo un delito que siempre se ha considerado detestable y execrable por la depravación de las costumbres. Por eso, los que buscan yacer con hombres y los que lo aceptaren por propia voluntad han de ser afectados por la sentencia de esta ley; o sea, que, tan pronto como el juez hubiere indagado que se ha cometido este delito, procurará que los dos sean emasculados inmediatamente y, después de entregarlos al obispo del territorio donde se ha cometido el delito, serán sometidos por separado a una dura penitencia para que al menos expíen, aunque de mala gana, aquellos actos ilícitos que perpetraron por propia voluntad. Pero si se sabe que alguno promovió o sufrió esta abominable deshonra, no voluntariamente sino contra su voluntad, podrá quedar exento de esta pena si él mismo denuncia este nefario delito; pero será sin duda sometido a la pena aquel que consta que se entregó voluntariamente a esta locura ${ }^{19}$.

De la lectura del fragmento, lo primero que se desprende es la fuerte repulsión que causa la homosexualidad masculina, que es percibida como una práctica abominable y vituperable. De hecho, el coito entre hombres es calificado como detestabilis, ex(s)ecrabilis, (h)orremdus y nefandus. Es una insania (una locura), pero también es inlicitus (un acto ilícito), por lo tanto, un scelus (delito) y, como tal, punible, comportando emasculación y penitencia para los culpables. Solo la segunda de estas penas podría remitir al aspecto religioso del delito, pero en el reino de Toledo era práctica habitual que la monarquía impusiese este sacramento como castigo civil. Puesto que comportaba exclusión social, se convirtió en un excelente medio, al que a menudo recurrió el poder político, para liberarse

19. L.I. 3.5.4, lins. 5-14. Utilizamos la edición y la traducción de Ramis SerRa, Ramis BARCELó 2015. 
de los elementos socialmente desestabilizadores o moralmente despreciables $^{20}$. Por lo tanto, que se imponga la penitencia a los hombres que practiquen sexo entre ellos refleja, más que el carácter religioso del delito cometido, el interés del legislador por alejarlos del resto de los mortales.

En el texto de la ley, no se alude a ninguno de los principios de la moral cristiana para condenar la homosexualidad masculina. Esa ausencia de referencias a la faceta pecaminosa de este tipo de conducta sexual ha llevado a Yolanda García López a barajar la posibilidad de que «moviera a Chindasvinto a legislar contra la pederastia un prejuicio social con raíces germánicas», aduciendo, como prueba, que en el "antiguo derecho noruego» también se decretaba la castración para actos similares ${ }^{21}$. La hipótesis nos parece cuestionable. Para empezar, creemos que el texto de la ley expone, con suficiente claridad, que lo que se está condenando es la práctica de la homosexualidad, no la pederastia, como afirma la autora. Además, dado que las primigenias poblaciones bárbaras no nos han legado documentación escrita, desconocemos cómo concebían las relaciones carnales entre hombres y alegar el "antiguo derecho noruego" como indicio de que las denostaban y perseguían supone aceptar que buena parte de esas poblaciones tenían su origen más remoto en la península escandinava. Asumir la veracidad de dicha procedencia implica admitir sin reservas el relato de los orígenes de los godos que Jordanes proporciona en la Getica, pero esa versión de los hechos no es más que un mito de origen, como lo define Lotte Hedeager ${ }^{22}$, que, en la actualidad, está prácticamente descartado. No parece, pues, que haya suficientes motivos para admitir que la ley de Chindasvinto derive de posibles prejuicios germánicos contra la homosexualidad, unos supuestos prejuicios que no confirman las codificaciones legales que vieron la luz en los distintos reinos surgidos tras la caída del Imperio romano occidental, en ninguna de las cuales se legisló contra las prácticas homosexuales ${ }^{23}$. En realidad, desconocemos por qué el rey visigodo decidió intervenir en esta materia, pero los pocos antecedentes existentes hay que buscarlos en la legislación tardo-imperial.

La única disposición regia sobre homosexualidad masculina que estaba en vigor en el momento en que se redactó la ley de Chindasvinto era una constitución de Teodosio II, del 438, en la que se condenaba, con

20. Remitimos a nuestro anterior trabajo, VALVERDE CASTRO 2003, 393-394, por contener abundantes referencias bibliográficas sobre el tema.

21. García López 1997, 311, n. 6.

22. 1993, 121-131.

23. Cfr. Boswell [1980] 1993, 202 y 204; Carrasco Manchado 2008, 118. 
la muerte en la hoguera, a los que adoptasen la actitud pasiva en una relación carnal entre hombres. Esta norma había sido incluida por Alarico II en la conocida como Lex Romana Visigothorum o Breviarium Alarici ${ }^{24}$, compilación legal elaborada con materiales romanos, que fue publicada en el año 506, durante la fase del reino tolosano, pero que aún seguía teniendo vigencia en la Hispania goda cuando reinaba Chindasvinto ${ }^{25}$. Sin embargo, no puede afirmarse que este rey visigodo se haya inspirado en la ley del Breviarium, porque son significativas las diferencias entre ambas disposiciones. En su normativa, ya deja de tenerse en cuenta la diferenciación, de tradición romana, entre amantes activos o pasivos y los dos miembros de la pareja son castigados, no con el suplicio del fuego, sino con la extirpación de sus órganos genitales, siendo, tras la amputación corporal, puestos bajo la tutela del obispo de la diócesis donde hubiese acontecido el delito, para que, por separado, ambos expiasen su culpa con una dura penitencia.

Asimismo, se perciben importantes diferencias entre las constituciones justineaneas contra la homosexualidad masculina y la ley de Chindasvinto, a pesar de que Justiniano, como ya hemos tenido ocasión de mencio$\operatorname{nar}^{26}$, haya sido el primer gobernante que anuló la tradicional distinción entre comportamientos sexuales activos y pasivos, al extender la condena a todos los participantes en el delito. El emperador bizantino, igual que hará el rey visigodo con más de un siglo de distancia temporal, también impuso la penitencia a los convictos e hizo intervenir a una autoridad eclesiástica, en su caso al patriarca, en la represión de los que practicaran sexo homosexual. Pero, aunque, como sostiene Yolanda García López ${ }^{27}$, se pueda "comparar la entrega que Chind. ordena del convicto al potifex territorii, con la denuncia (pero más bien la auto-denuncia) ante el patriarca que recomienda Justiniano", en la ley visigoda, la intervención episcopal se produce después de que los reos ya hayan sido condenados y su finalidad es tutelar a los reclusos, mientras que, en la disposición bizantina, no sólo se prescribe la "auto-denuncia» ante el patriarca, que, por tanto, es anterior al juicio, sino que además se prevé la posibilidad de

24. Véase Cantarella [1988] 1991, 232, con transcripción y traducción del texto de la ley ( $L R V$ 8.4.5).

25. Se discute si con la promulgación del Liber Iudiciorum se derogó el Breviarium, pero no parece haber dudas de que, cuando menos, se mantuvo en vigor hasta entonces. Una síntesis de esta problemática en Alvarado Planas 1997, 58-70.

26. Vid. supra, p. 277.

27. 1997,315 , n. 26. 
indultar a los que dejen de cometer el acto delictivo ${ }^{28}$. No hay perdón para los que modifiquen su comportamiento en la L.I. 3.5.4. Solo en el caso de que alguien haya sido forzado a sufrir el orrendum dedecus ("la abominable deshonra") en contra de su voluntad, podrá evitarse el castigo, siempre y cuando el agredido denuncie al agresor. Otro aspecto que distingue sus respectivas disposiciones es que el constante énfasis en el carácter religioso del delito, que hace Justiniano, falta en la ley de Chindasvinto. Además, el emperador no impuso la castración como castigo, sino la pena de muerte ${ }^{29}$. Por lo tanto, tampoco puede establecerse un vínculo de relación directa entre ambas normativas. Parece, pues, que aunque las escasas normas imperiales sobre la materia quizá puedan haber influido en la elaboración de la primera ley que vio la luz en el reino de Toledo contra la homosexualidad masculina ${ }^{30}$, hubo, sin duda, aspectos novedosos que respondieron a una formulación propia de los juristas de Chindasvinto.

No obstante, la pena de emasculación que se establece en la ley visigoda, aunque no esté contemplada ni en el Breviarium de Alarico ni en las constituciones de Justiniano, no era ajena a las prácticas represivas

28. Iust., Nov. 141.1: [...] qui autem boc affectu iam computruerunt, non solum in posterum ab eo desistant, sed etiam memtam poenitentiam agant et deo se submittant, et beatissimo patriarchae morbum denuntient et sanationis rationem accipiant, et secundum id quod scriptum est fructum ferant paenitentiae [...]. Denuntiamus autem omnibus deinceps qui eusmodi alicuis peccati sibi conscii sunt, nisi et peccare desierent et se ipsi beatissimo patriarchae deferentes prorpriae saluti prospexerint [...], acerbiores sibi poenas arcessituros esse, quippe qui nulla in posterum uenia dingi sint [...]; "[...] pero quien por el contrario se haya ya manchado no sólo debe cesar en el futuro, sino que debe hacer justa penitencia y postrarse a los pies de Dios y denunciar su mal al beatísimo patriarca para recibir su curación y llevar la penitencia que le corresponda según lo escrito [...]. Notificamos además, que todos aquellos que sean conscientes de que han pecado en alguno de estos modos, si no desisten, y una vez que tenga conocimiento el beatísimo patriarca, no se preocupen de su propia salvación por sus impías acciones [...], caerán sobre ellos las penas más atroces negándoseles la indulgencia». (Siempre que reproduzcamos algún fragmento de las leyes de Justiniano que condenan la homosexualidad, el texto latino y la traducción estarán tomados de Espejo Muriel 1991, 189-191 y 229-231).

29. Pueden observarse estas diferencias en los análisis que Cantarella [1988] 1991, 233 236 y Espejo Muriel 1991, 188-191, han realizado de las tres disposiciones (Inst. 4.18.4, Nov. 77 y Nov. 141) dadas por Justiniano sobre la materia que nos ocupa.

30. No hay unanimidad al respecto. Rafael Ureña no duda de que la legislación de Justiniano, habiendo estado vigente en la provincia bizantina de la península ibérica, era conocida en la Hispania goda (hemos utilizado la reedición de la obra que ha sido hecha por Carlos Petit: Ureña y Smenjaud [1905] 2003, 250 y 337). En cambio, García López 1997, 315 , cree que "no hay ningún indicio formal suficientemente significativo para asegurar" que los redactores de las normas visigodas contra la homosexualidad conocieran las disposiciones de Justiniano sobre la materia. 
tardo-romanas y bizantinas. Eva Cantarella ${ }^{31}$ ha demostrado que, en el derecho imperial, al menos desde el siglo iv, no eran infrecuentes las infracciones en las que se prescribía la mutilación de los órganos corporales que, real o simbólicamente, hubiesen intervenido en la ejecución de las mismas. La castración suponía privar al homosexual activo de la parte del cuerpo que había cometido el delito y, al pasivo, de la virilidad a la que había renunciado con su conducta, por lo que la autora baraja la posibilidad de que este tipo de amputación fuese el suplicio al que indirectamente aluden Constancio y Constante en su ley sobre la homosexualidad pasiva del año 342. Le induce a creerlo que ese fuese el castigo que, según revelan las fuentes literarias, aplicó Justiniano a los condenados por mantener relaciones homosexuales antes de decretar la pena de muerte para esta clase de reos. Por lo tanto, parece adecuado descartar que la emasculación que prescribe la ley 3.5.4 sea una absoluta innovación de los juristas de Chindasvinto.

Uno de los aspectos más novedosos de la norma visigoda es que contemple las repercusiones que la condena por homosexualidad tendría para los familiares de los convictos. Lo hace al final del texto de la ley, donde se establece que:

Habentes autem uxores, qui de consensu talia gesserint, facultatem eorum filii aut heredes legitimi poterunt obtinere; nam coniuge, sua tantum dotem percepta suarumque rerum integriate retenta, nubendi cui voluerint indubitata manebit et absoluta licentia.

Asimismo, si, teniendo mujer, ha cometido estos actos con pleno consentimiento, sus hijos o sus herederos legítimos podrán obtener sus bienes; y la mujer, después de recibir únicamente lo que le pertenece como dote y reteniendo íntegramente sus propios bienes, tendrá sin duda licencia absoluta para casarse con quien quisiere ${ }^{32}$.

Constatamos cómo, probada la comisión del delito, la sentencia afectaba, además de al reo, a sus herederos y, en particular modo, a su legítima esposa. Descubrimos aquí dos de los rasgos que, según Paul D. King, mejor definen al derecho de familia en el regnum Toletanum: la preocupación regia por proteger a los hijos y la mejora de la condición legal de las mujeres, que se percibe, con especial claridad, en la desaparición de la antigua preferencia romana por un régimen de sucesión de carácter agnaticio ${ }^{33}$. De

31. [1988] 1991, 224-227 y 236-238.

32. L.I. 3.5.4, lins. $14-17$.

33. KING [1972] 1981, 250. Es necesario precisar, no obstante, que ya en la Antigüedad tardía, el derecho sucesorio pasó a ser de tipo cognaticio (véase BARBIERA 2012, 147-148) y 
hecho, cuando se utiliza el plural para referirse a la prole que adquirirá los bienes de su progenitor en el caso de que este hubiese sido condenado por haber mantenido relaciones homosexuales, sin duda se está haciendo alusión tanto a los hijos como a las hijas del convicto, pues el derecho sucesorio visigodo no establecía ninguna distinción por sexo entre los legítimos herederos ${ }^{34}$. A mujeres y a hombres, por tanto, también estaría haciendo referencia el texto cuando reconoce los derechos del resto de los posibles herederos, que serían, según regulan las leyes que abordan los casos de sucesión intestada, los nietos y los biznietos; en su defecto, los ascendientes, primero los padres y después los abuelos. De no existir familiares en línea directa, los bienes pasarían a los colaterales ${ }^{35}$. Ahora bien, puesto «que los hijos son los primeros en la sucesión hereditaria ${ }^{36}$, los demás parientes solo podrían disfrutar de las posesiones del reo en el caso que de este no tuviese hijos. Por lo tanto, parece que la ley de Chindasvinto está contemplando los dos supuestos posibles cuando condena a un hombre por tener relaciones carnales con otro hombre: que el convicto tuviese hijos o que careciese de descendencia y, en cualquiera de los casos, al reo condenado se le aplicaba una sanción económica, pues siempre perdía sus bienes en favor de sus herederos.

En el terreno económico, también resultaba perjudicado por el hecho de que la sentencia condenatoria estableciera la disolución de su vínculo matrimonial, lo que le privaba de la posibilidad de obtener beneficios con la gestión de las propiedades de su esposa ${ }^{37}$. A ella, además de reconocerle el derecho a conservar sus propios bienes, se le permitía recuperar la totalidad de su dote, una dote que era entregada por el novio a su futura mujer y cuya cuantía se fijaba en la ceremonia esponsalicia,

que esa promoción femenina solo se mantuvo en la Hispania goda, pues, como sostiene Wicкнам [2005] 2008, 785-786, «en el resto de los reinos germánicos la herencia de las mujeres estaba sujeta a mayores restricciones».

34. Baste citar para probarlo dos de las leyes del L.I. que, con contundencia, reconocen la igualdad de hombres y mujeres a la hora de heredar: la antiqua 4.2.1, Ut sorores cum fratribus equaliter in parentum bereditatemsuccedant ("Que las hermanas tengan parte en la herencia igual que los hermanos") y la 4.2.9, de Chindasvinto, Quod in omnem hereditatem femina accipi debeat ("Que en toda herencia las mujeres han de ser admitidas").

35. Son las leyes 4.2.2 y 4.2.3 las que regulan el orden de sucesión en caso de defunción intestada. sunt.

36. Así reza el título de la antiqua 4.2.2: Quod in hereditatis successione filli primi

37. Dicha posibilidad está claramente contemplada en la antiqua 4.2.15, que permite al marido utilizar los siervos de su mujer, sin que ella pueda reclamar nada de las ganancias obtenidas por el uso de sus dependientes. 
que ya convertía en irrevocable el compromiso nupcial ${ }^{38}$. Protegida económicamente por estas medidas, la esposa ultrajada también podía volver a casarse. Su condición quedaba así equiparada, en buena medida, a la de la viudez, el estado en el que la mujer disponía de mayor libertad de acción. Era cuando podía administrar su patrimonio, ejercer la tutela sobre sus hijos menores y adoptar la decisión personal de contraer nuevas nupcias $^{39}$. Otra ley de Chindasvinto, la 3.6.2, donde se regulan los casos en los que se admitía el divorcio unilateral ${ }^{40}$, insiste en reconocer ese derecho a toda mujer que hubiese sido traicionada por su esposo con otro hombre. En ella se establece que:

[...] si mulieris maritus masculorum concubitor adprobatur, aut eandem suam uxorem, ea nolente, adulteranda cuicumque viro dedisse vel permisisse convincitur [...], nubendi mulieri alteri viro, si volumtas eius exititerit, nullatenus inlicitum erit.

[...] si se demuestra que el marido de la mujer tenía relaciones carnales con hombres o bien es convicto de haber dado a su mujer a otro hombre para que cometiera con ella adulterio en contra de su voluntad, o de haberlo consentido [...], no se impedirá que la mujer se case con otro hombre ${ }^{41}$.

Que el marido indujera a su esposa a fornicar con otros individuos, que permitiese ese comportamiento, o bien, que él mismo mantuviera encuentros sexuales con sus congéneres, eran las únicas circunstancias, aparte de la muerte, que hacían posible que la mujer se liberase, por completo, del vínculo matrimonial. Observamos, pues, que solo se admitía el repudio femenino cuando se violaba el inquebrantable principio de

38. Aunque la atención de la legislación visigoda se centre, sobre todo, en los bienes que el marido entregaba a la mujer, no se excluye que la familia de la esposa también hiciese algún tipo de aportación económica. Sobre estos particulares, puede verse OtERO 1959, 545-555; King [1972] 1981, 251-254; DubreucQ 2005, 36-49.

39. Cfr. Wemple 1991, 190; Jiménez Garnica 1995, 148; Santineldi 2003, 254-255. Un estudio exhaustivo sobre cómo se trataba la viudedad en los códigos legislativos visigodos en GACTO FERNÁNDEZ 1975.

40. Según Martin 2015, 93-100, a pesar del título de la ley, Ne inter coniuges divortium fiat ("Que no haya divorcio entre los cónyuges»), que, a simple vista, induce a pensar que se está proclamando la indisolubilidad del matrimonio, lo que representaría un unicum en el derecho occidental de los siglos vi y vII, la norma visigoda no hace más que seguir la línea de la constitución constantiniana del 331, en la que, por primera vez, se introdujo la noción de "causas justas» para el divorcio unilateral, sin que, por lo tanto, resulte excepcional.

41. L.I. 3.6.2, líns. 14-17. 
la fidelidad conyugal ${ }^{42}$. En consonancia con esta mentalidad, también se prescribía la separación de los cónyuges en caso de adulterio, pero en el reino de Toledo solo se contemplaba la posibilidad de que este delito fuera cometido por las mujeres, por lo que solo ellas eran castigadas por este motivo ${ }^{43}$. Por lo tanto, el único fornicio masculino extramatrimonial que se penalizaba era el homosexual.

Recapitulando, a mediados del siglo viI vio la luz la primera de las leyes elaboradas por los juristas de un rey godo, Chindasvinto, que penalizaba, con suma dureza, la homosexualidad masculina. Siguiendo tradiciones imperiales, aunque sin ser una copia literal de las disposiciones tardo-romanas y bizantinas, y asimilando el sexo entre hombres a una horrenda perversión, la norma regia comportaba cuatro tipos de castigos para todos los que, voluntariamente, mantuviesen relaciones homosexuales: una mutilación corporal, la emasculación, el alejamiento del mundo que suponía la imposición de la condición de penitente, la disolución del vínculo matrimonial y una sanción económica, pues, aunque el convicto siguiese con vida, ya perdía sus bienes a favor de sus herederos.

\section{LAS Disposiciones de EGICA: UNA NORMA CONCILIAR Y UNA LEY REGIA}

Casi cuarenta años después de la promulgación del Liber Iudiciorum de Recesvinto, en el Concilio XVI de Toledo, que fue inaugurado el día 2 de mayo del 693, se adoptó la primera resolución sinodal contra las prácticas homosexuales en la Hispania goda. Los nobles y los eclesiásticos en él congregados actuaron por mandato expreso de Egica (687-702), el rey que los convocó, y quien, en el tomus que entregó a los presentes, ordenó:

Inter cetera tamen obscoenum crimen illud de concubitoribus masculorum extirpandum decernite, quorum horrenda actio et honestae vitae gratiam maculat et iram coelitus superni vindicis provocat.

Igualmente, entre otros crímenes, debéis decretar el exterminio de aquel crimen obsceno que es la homosexualidad, cuyas prácticas horrendas ensucian la gracia de una vida honesta y provocan la ira del Supremo Vengador que está en los cielos ${ }^{44}$.

42. Lo deja claro la prescripción contenida en la misma L.I. 3.6.2, que impide volver a casarse a la esposa de un hombre dado como siervo a otro, hasta que él no fallezca, porque «está obligada a quedar bajo el freno de una vida de castidad» (caste vite freno manere constrictam).

43. Cfr. Álvarez Cora 1997, $23-24$ y 41-42; Gallego Franco 2004, 622. De forma monográfica, ToRrent 2017a, 1-75, estudia la regulación sobre el adulterio en el reino de Toledo.

44. Tol. XVI, Tomus, p. 487. Utilizamos la edición y la traducción de Vives, Martín Martínez, Martínez Díez 1963. 
Ya en este contundente y directo mandato regio, descubrimos un cambio, tanto de enfoque, como de intenciones, con respecto a la ley de Chindasvinto. Aunque el sexo entre hombres sigue recibiendo la misma denominación, concubitores masculorum, que se le daba en la norma 3.5.4, de detestable y execrable "delito que no debe dejarse sin castigo" (non relinquendum est scelus inultum), ha pasado a ser un "crimen obsceno" (obscoentum crimen) que atenta contra la divinidad. Es decir, el acto ilícito, el delito profano de la ley de Chindasvinto, se ha vuelto un pecado, se ha transformado en una gravísima falta de carácter religioso, que desencadena la "ira del supremo vengador ${ }^{45}$ (iram [...] superni vindicis provocat). Por lo tanto, no basta la punición. Ahora hay que exterminar por completo esas «acciones horrendas" (horrenda actio), porque su erradicación es el único medio de evitar el castigo ultraterreno, las terribles consecuencias que la práctica de la homosexualidad, de no concluir, acarrearía para el conjunto de la sociedad.

Esta nueva óptica de carácter religioso con que se juzga la homosexualidad no hace sino desarrollarse en la resolución que, siguiendo las indicaciones del monarca, se adoptó en el canon 3 del Concilio XVI de Toledo. Tanto en el título que precede a la norma conciliar, como en el doble proemio que se antepone a la fijación de la condena, el énfasis se pone en el aspecto pecaminoso que se atribuye a las relaciones carnales entre hombres. Reza así:

\section{De sodomitis}

Sicut cordis corporisque munditia homines Deo proximos facit, ita incestivae pollutionis actio a Deo alienos statuit, et sicut Sodomiticos populos horrenda nimiumque detestanda patratio igne caelitus confluenti exurendos in praeteritis tradidit, ita talibus inmunditiis homines deditos aeternae damnationis rogus consummet, loquente Domino per prophetam: "Vestimentum mixtum sanguine erit in combuistione et cibus ignis." At nunc quoniam haec funesta actio et sodomiticae operationis malum multos sauciasse perpenditus, adeo nos ob huius foedissimae causae extirpandam consuetudinem zelo Domini ardentes omnes in conmune sanccimus, ut quique huius nefariae actionis patratores extiterint quique in his turpitudinibus sese implicari permiserint et contra naturam masculi in masculos hanc turpitudinem operaverint, [...].

45. Con esta expresión, según García López, 1997, 314, Egica se está haciendo eco de la tradición cristiana, presente en Pablo de Tarso, Agustín de Hipona o el Ambrosiaster, cuyas condenas «de la pederastia aparecen casi siempre enlazadas a ese Deus iratus y a la destrucción por el fuego». 
De los sodomitas

Así como la limpieza de corazón y de cuerpo hace que los hombres se aproximen a Dios, por el contrario, la práctica de las torpezas incestuosas los aparta de Él y así como el horrendo y detestable crimen en los tiempos pasados entregó a los pueblos sodomíticos para ser abrasados por el fuego que venía del cielo, del mismo modo el fuego de la eterna condenación consumirá a los hombres que se entreguen a semejantes inmundicias, pues el Señor dice por medio del profeta: "La vestidura mezclada con sangre, será abrasada y alimento del fuego». Ahora bien, porque esta funesta práctica y el vicio del pecado sodomítico parece haber inficionado a muchos, nosotros, para extirpar la costumbre de esta práctica vergonzosa, abrasados por el celo del Señor, todos de común acuerdo, sancionamos que todos los que aparecieren ejecutores de una acción tan criminal, y todos aquellos que se hallaren mezclados en estas torpezas y, obrando contra naturaleza, hombres con hombres cometieren esta torpeza, [... $]^{46}$.

Constatamos como, frente a la norma del Liber, donde se combatía la homosexualidad masculina por representar una depravación de las costumbres, ahora es la necesidad de agradar a Dios, el estar «abrasados por el celo del Señor» (zelo Domini ardentes), lo que justifica la actuación de los conciliares. Desde las primeras líneas del texto, aflora la estima cristiana por la pureza sexual, imprescindible para lograr la proximidad a Dios o, lo que es lo mismo, para acceder al paraíso y se manifiesta, en consecuencia, el característico desprecio de la moral vigente por los placeres de la carne. Con constantes y durísimos vituperios, calificándola, entre otras cosas, de crimen horrendo y detestable, inmundo y vergonzoso, la homosexualidad se presenta como una de las peores desviaciones sexuales que un hombre puede cometer, porque le aleja de la divinidad o, en otras palabras, le condena eternamente. Y, como es lógico, ya se remite a pasajes bíblicos para demostrar esos principios doctrinales que ahora justifican la persecución y el castigo de las relaciones homosexuales. Por primera y única vez en la normativa visigoda, se alude al carácter antinatural del coito entre hombres, una más que probable reminiscencia del pasaje paulino, contenido en la Epístola a los romanos 1.26-27, en el que se afirma:

Por esto Dios los ha abandonado a sus bajas pasiones. De hecho, sus mujeres cambiaron el uso natural por el «contra natura». Pero, igualmente los hombres, abandonando el uso natural de la mujer, recíprocamente se dedicaban a los más bajos deseos, cometiendo los hombres así tórpida acción con otros hombres, y recibiendo en sí mismos la merced debida a su propia culpa.

46. Tol. XVI, c. 3, p. 500. 
Se trata de un texto clave para el desarrollo posterior de la moral sexual cristiana porque, frente al desinterés de Jesús por las conductas homosexuales, Pablo ya reprueba en él toda relación carnal entre personas del mismo género, incluyendo a las mujeres en la condena, lo que resulta excepcional porque ellas solían ser las grandes olvidadas cuando se abordaba el tema de la homosexualidad en el mundo antiguo $^{47}$. Sin embargo, para mostrar que el único acoplamiento «natural» es el de carácter heterosexual, su mención resultaba imprescindible. Pablo, obviando las típicas consideraciones romanas al comportamiento activo o pasivo, a la condición social o a la edad de los implicados en la relación, vigentes en el siglo i d. C. que le tocó vivir, está introduciendo una nueva forma de tratar el problema, en la que la dicotomía homosexualidad/heterosexualidad resulta fundamental porque, en el nuevo orden "natural" predispuesto por Dios, la finalidad del sexo es exclusivamente reproductiva ${ }^{48}$. Esa trascendental innovación de la predicación paulina, que convierte en fornicación contra naturam, en pecado contra Dios, a toda cópula no encaminada a la procreación, resuena en el concilio toledano al afirmar que "obrando contra naturaleza, hombres con hombres cometieren esta torpeza" (contra naturam masculi in masculos hanc turpitudinem operaverint), pero no puede ser más evidente que los conciliares siguen considerando únicamente la homosexualidad masculina, omitiendo por completo la posibilidad de que las mujeres pudieran cometer tan aberrante acción. De hecho, ni en esta ni en ninguna de las otras normas que penalizan la cópula homosexual en el reino de Toledo se tiene en cuenta a las mujeres, un posible reflejo del carácter

47. No deja de resultar curioso que, aunque el actual término lesbianismo derive del nombre de la isla griega de Lesbos, donde, en torno a la segunda mitad del siglo VII, sobresalió la poesía homoerótica de Safo, el vocablo, en origen, según defiende Gentili 1989, 131, tenía que ver con el sexo oral, la especialidad amatoria de las muchachas de la isla, no con el practicado entre mujeres, y que, como afirma Cantarella [1988] 1991, 215-219, las relaciones homoeróticas entre mujeres no hayan tenido cabida ni en las leyes del mundo griego ni en las reflexiones de sus filósofos. La autora también mantiene (215-219) que ninguna ley romana condenó la homosexualidad femenina, a pesar de ser concebida como "la peor de las depravaciones a los ojos de los romanos" (p. 215). En el mismo sentido, se manifiesta BRundage [1987] 2000, 45, quien además destaca que en las Sagradas Escrituras apenas se menciona el sexo lésbico (76). Igualmente escasean los comentarios sobre la homosexualidad femenina en las fuentes patrísticas (Boswell [1980] 1993, 184-185; Kuefler 2019, 232-233).

48. Frente a esta interpretación del mensaje paulino, que es la más difundida (Cantarella [1988] 1991, 226-249; Espejo Muriel 1991, 176; Borillo 2016, 4), Boswell [1980] 1993, 132-136, defiende que Pablo solo condena los actos homosexuales llevados a cabo por personas aparentemente heterosexuales, pero su interpretación resulta bastante forzada. 
androcéntrico de la sociedad visigoda ${ }^{49}$. La mujer, como afirma Henar Gallego Franco ${ }^{50}$,

no tiene, ni debe tener, sexualidad activa [...] y por ello las únicas prácticas homosexuales que se condenan, tanto en los cánones conciliares, como en la Lex Visigothorum, son las masculinas.

Otra innovación del canon 3 del Concilio XVI es que, por primera vez en la legislación hispana contra la homosexualidad, se aplica el término bíblico "sodomita» al que mantiene relaciones carnales con sus congéneres. Aunque el término, como es de sobra conocido, deriva del célebre pasaje veterotestamentario (Génesis, 19) donde se narra la aniquilación de los habitantes de Sodoma mediante una lluvia de fuego y azufre enviada por Yavé para castigarlos por entregarse a una vida disoluta, no hay acuerdo sobre cuál fue el significado primigenio de este relato. Se discute si siempre se ha atribuido una naturaleza sexual, más en concreto homosexual, al pecado cometido por los sodomitas, o si, por el contrario, esta interpretación deriva de la tradición postbíblica y, en origen, se concebía que el motivo fundamental que desencadenó la furia divina fue la violación de las leyes de la hospitalidad, de obligado cumplimiento en el mundo antiguo $^{51}$. Se ha defendido que fue en la Edad Media, a partir del siglo $\mathrm{x}$, cuando terminó triunfando la versión que descubría un componente sexual en la transgresión cometida por los sodomitas ${ }^{52}$, pero es evidente que en el canon toledano ya se ha impuesto ese tipo de explicación del relato del Génesis. Sin dejar espacio para la duda, sodomía se emplea con el significado hodierno de coito anal, aunque restringido al practicado entre hombres ${ }^{53}$.

49. Es el motivo que Bailey 1955, 162, esgrimió, en su día, para explicar por qué los antiguos hebreos tendieron a ignorar el lesbianismo, probablemente extrapolable a otras sociedades.

50. 2004,625 .

51. La controversia se inserta en el debate, más amplio, sobre si toda conducta homosexual fue o no condenada en el Antiguo Testamento, discutiéndose también si ese posible rechazo judío del sexo entre hombres fue una de las causas que motivó la hostilidad cristiana hacia las relaciones homosexuales. Baste remitir a CANTARELla [1988] 1991, 249-260 y a Boswell [1980] 1993, 117-125, quienes, manteniendo posturas enfrentadas (a favor la primera, en contra el segundo), sintetizan los aspectos más destacados de esta polémica.

52. Carrasco Manchado 2008, 127.

53. No era la única interpretación que pervivía en la Hispania goda, pues cuando Isidoro en sus Sententiae (2.42.2.) alude a Sodoma afirma que sus habitantes fueron exterminados por sus desmedidas ansias de comer, es decir, por el pecado de la gula, que desata la lujuria, aunque sin especificar que esta fuera de carácter homosexual. 
Los conciliares, al utilizar el derivado del término para designar a los homosexuales, no hacen más que seguir la senda trazada por Justiniano en esas primeras leyes en las que el emperador bizantino ya castigó toda relación carnal entre hombres. En las Novellae de Justiniano aún no se usa el vocablo "Sodomita" para aludir al que practica la homosexualidad, pero sí se remite a la destrucción de Sodoma para justificar su persecución ${ }^{54}$. Las referencias al relato bíblico sirven para probar que mantener relaciones homosexuales puede reportar terribles consecuencias para el conjunto de la población. Aunque sean individuos concretos los que ofendan a Dios con tales prácticas, su furor, que desencadena todo tipo de catástrofes naturales, no les afectará solo a ellos, sino que repercutirá en toda la sociedad. La misma idea, es decir, la convicción de que la comisión del pecado sodomítico acarrea un castigo comunitario, está implícita en la orden de Egica, aunque los conciliares solo remiten al pasaje del Génesis para justificar el fin al que están abocados los homosexuales, quienes, como los sodomitas bíblicos, serán abrasados por las llamas, estos, por las que descienden de los cielos y, aquellos, por el rogus aeternae, «el fuego de la eterna condenación".

De acuerdo con estos presupuestos, la condena que se fija en la norma conciliar es extremadamente dura y, como cabe esperar tras lo expuesto en el preámbulo de la sentencia, no se contempla en ella ninguna posibilidad de perdón para los sodomitas. Los reunidos en Toledo XVI establecen:

[...] si quiden si episcopus, presbyter aut diaconus fuerit, de propii honoris gradu deiectus perpetui exili manebit damnatione perculsus; sin

54. Se hace de forma indirecta en la Nov. 77 , pr. y cap. 1 (Docemur enim a diuinis scripturis, quia ex huiusmodi impiis actibus et ciuitates cum hominibus pariter perierunt. [...] Propter talia enim delicta et fames et terrae motus et pestilentiae fiunt; "De hecho, las escrituras nos enseñan que, por tales impías actuaciones, cayeron en desgracia con los hombres las ciudades. [...] Por tales delitos sufrimos las carestías, los terremotos y las pestes») y explícitamente en la 141.1 (Scimus enim ex sacris scripturis edocti, quale deus iustum supplicium iis qui Sodomis olim habitarunt, propter hunc in commixtione furorem intulerit, adeo ut in buc usque diem regio illa inextincto igni ardeat, cum deus per hoc nos erudiat, ut impiam istam actionem auersemur. [...] ne per neglegentiam hac in re commissam deum contra nos irritemus, si actionem tam impiam et probibitam praetermittamus quaeque idonea sit ad bonum deum in omnium perniciem irritandum; "Pues sabemos de hecho, por las sagradas escrituras, el justo castigo que Dios envió a los que un tiempo habitaban Sodoma, debido a sus nefandas pasiones, de tal modo que hasta hoy arde esa tierra con fuego perenne, mostrándonos Dios, a través de esto, cómo nos debe repugnar tal acción impía. [...] no sea que por dejadez irritemos a Dios contra nosotros, al no darnos cuenta de que una acción tan impía y prohibida que es capaz de irritar al buen Dios para desgracia de todos nosotros»). 
vero cuiuslibet ordinis, gradus sive personae et alterius colluvionis noxiis reperti fuerint inplicati, illius legis quae de talibus est edita nibilhominus ferientur sententia atque ab omni christianorum sint alieni caterva, et insuper centenis verberibus correpti ac turpiter decalvati exilio mancipentur perpetuo; ita ut nisi tam eos qui religionis cultum turpasse visi sunt quam etiam alios, ut diximus, cuiuscumque ordinis bomines digna satisfactio poenitentiae accipere corpus et sanguinem Christi in fine permiserit, aut christicolarum societati redierit, nec in exitus sui die secundum canonum instituta communionis perceptione se noverint relevari nec catholicorum coetui adgregari.

[...] si alguno de ellos fuere obispo, presbítero o diácono, desposeído del grado del propio honor será condenado a destierro perpetuo; pero si otras personas de cualquier orden o grado, se les hallare complicadas en crímenes tan afrentosos, sufrirán, no obstante, el rigor de aquella ley que se promulgó en contra de los tales y separados de la asamblea de los cristianos, corregidos además con cien azotes, y vergonzosamente rasurados, serán condenados al destierro perpetuo; de tal modo que a no ser que una digna satisfacción penitencial les permitiere recibir al fin de su vida el cuerpo y la sangre de Cristo, o los restituyere a la sociedad de los cristianos, tanto aquellos que deshonraron el culto debido a la religión como aquellos otros hombres de cualquier grado, como dijimos, sepan que ni al fin de su vida, conforme a lo establecido en los cánones, serán consolados con la recepción de la comunión, ni agregados a la comunidad cristiana ${ }^{55}$.

Observamos que los conciliares marcan una clara distinción entre eclesiásticos y seglares a la hora de fijar la condena por homosexualidad. No es extraño que, siendo una norma decretada en una reunión sinodal, las penas fueran más benévolas para los eclesiásticos que para los laicos. Para los primeros, sin tener en cuenta la posición que ostentasen dentro de la jerarquía clerical, es decir, con independencia de que fueran obispos, presbíteros o diáconos, se prevé la reducción al estado laical y el exilio perpetuo. Para los segundos, además de añadir la excomunión de por vida al destierro permanente, se decretan severos castigos corporales: los que copulen con otros hombres recibirán cien latigazos y también serán turpiter decalvati, una expresión que, en la edición castellana del texto, se traduce por "vergonzosamente rasurados», pero es necesario matizar que no está claro que la decalvación consistiera simplemente en cortar al cero el pelo de los condenados. Se ha sugerido que en la Hispania goda pudieron haberse practicado diferentes tipos o gradaciones de decalvatio y es muy posible que la más dura de todas, con toda probabilidad aplicada a los conspiradores políticos, implicara arrancar al reo una parte o

55. Tol. XVI, c. 3, pp. 500-501. 
la totalidad del cuero cabelludo ${ }^{56}$. Las palabras de la resolución conciliar no permiten determinar qué tipo de decalvación se aplicaba a los homosexuales, pero el fuerte desprecio hacia ellos que se manifiesta en las fuentes y el que se les impongan las mismas penas que a los acusados por delitos de traición ${ }^{57}$, un claro indicio de la gravedad que se atribuía a la práctica de la homosexualidad, induce a pensar que la decalvación prescrita implicaría, en su caso, un castigo físico que sobrepasaría el mero escarnio público de un afeitado de cabeza ${ }^{58}$.

A los azotes y la decalvación, se añadiría, en el caso de los laicos, otra pena corporal, la emasculación, pues, como ya hemos tenido ocasión de constatar, ese era el castigo previsto por Chindasvinto en su ley 3.5.4. Esta era la única disposición sobre la materia vigente en el momento en que se reunió el Concilio XVI de Toledo y, por lo tanto, es a ella a la que se estaría haciendo referencia cuando se afirma que los homosexuales también sufrirán "el rigor de aquella ley que se promulgó en contra de los tales" (illius legis quae de talibus est edita nibilhominus ferientur sententia) ${ }^{59}$.

Más difícil resulta determinar a qué están aludiendo los conciliares cuando remiten a lo establecido en otros cánones para reforzar la inderogabilidad de la excomunión impuesta, porque Toledo XVI fue el primer y único sínodo celebrado en el regnum Toletanum en el que se abordó el tema de la homosexualidad. Luis García Iglesias ${ }^{60}$, alegando que las normas contra las relaciones carnales entre hombres englobaban también el afán por erradicar la pederastia, no duda en defender que uno de los cánones referidos era el 71 del Concilio de Elvira, celebrado en época constantiniana, a principios del siglo iv, donde ya se había decretado la excomunión perpetua para los adultos que abusaran de muchachos ${ }^{61}$. Pero, salvo esta disposición y la de Toledo XVI, no se conoce ninguna otra norma eclesiástica peninsular donde se haya condenado ni la homo-

56. LeAr 1951, 15-16; ArCe 2011, 154-157; Crouch 2010, 59-77.

57. La ley de Chindasvinto 2.1.8 es clara al respecto. Establece: [...] decalvatus tamen $C$ flagela suscipiat et sub artiori vel perpetuo erit religandus exilio pene [...] («[...] después de decalvarlo, que reciba cien azotes, que sea castigado con el exilio perpetuo y más alejado posible $[\ldots] »)$, refiriéndose al que, habiéndose rebelado contra el rey, se le haya conmutado la pena de muerte prescrita para este tipo de reos.

58. El escarnio público, no obstante, representaba un aspecto importante en el sistema punitivo visigodo, pues, como ha afirmado Díaz 2003, 206, «el secreto del suplicio no habría tenido sentido alguno: había que generar, mediante el espectáculo de la ejecución, conciencia de castigo y temor».

59. Tanto García Iglesias 1976, 85, como García López 1997, 309, comparten esta opinión.

60. 1976,85 .

61. Conc. Elib. c. 71, p. 14: Stupratoribus puerorum nec in finem dandam esse conmunionem; «A los estupradores de niños, niégueseles la comunión, aún a la hora de la muerte». 
sexualidad ni la pederastia. Es cierto que en las reglas monásticas hispano-visigodas se incluían preceptos para combatir ese tipo de conductas $^{62}$, pero aunque, como afirma Pablo C. Díaz ${ }^{63}$, «la Iglesia aceptaba y sancionaba estas Reglas, que eran de indudable aplicación en los monasterios que las seguían", no eran equivalentes a los cánones aplicables en el conjunto de los territorios del reino, por lo que no sirven para explicar ese plural usado por los conciliares.

Tampoco es fácil de entender la contradicción, al menos aparente, de las palabras que cierran el canon 3 del Concilio XVI de Toledo, donde, por un lado, se establece que los condenados no podrán recibir la comunión, ni siquiera al final de sus días, y, por otro, se contempla la posibilidad de que una penitencia adecuada les permita volver a comulgar antes de fallecer. La sensación que se obtiene de la lectura del canon es que la primera de estas disposiciones iba destinada a los eclesiásticos y, la segunda, a los laicos. La diferenciación no carece de sentido, pues siendo mayor la gravedad de la ofensa cometida contra Dios en el caso de los clérigos, es lógico que se les privara de la posibilidad de ser perdonados, incluso en el momento de la muerte. No obstante, dada la severidad de los castigos corporales que se imponían a los seglares que mantenían relaciones homosexuales, es probable que muchos fallecieran tras la aplicación de esas penas. Serían pocos, pues, los que tendrían la opción de recibir la ansiada comunión, que podía abrirles las puertas de la salvación eterna.

Aun así, a Egica no le bastó con la norma que, siguiendo sus indicaciones, dictaron los padres conciliares. No fue suficiente para él ni la dureza de las penas que en ella se fijaron, ni que se convirtiera, como el resto de los cánones del sínodo, en una disposición aplicable en los tribunales de justicia del regnum por medio de la lex in confirmatione concilii con la que se clausuró el Concilio XVI de Toledo ${ }^{64}$. Egica promulgó

62. La regulación al respecto es, en buena medida, preventiva y se caracteriza por su concreción. Para que no caigan en la tentación de mantener contactos homoeróticos, se prohíbe a los monjes besar a los más pequeños y dormir juntos, se fija la distancia que tiene que haber entre los lechos o se pone vigilancia especial en los retretes. Véase García Iglesias 1976, 92-93; IbáÑez Aller 1999, 765-766. Ambos autores abordan la cuestión, pero lo hacen de forma sintética y solo se centran en las reglas de Isidoro y de Fructuoso. El análisis de la normativa sobre homosexualidad y pederastia en las reglas monásticas de la Hispania goda requeriría un estudio específico que no se ha realizado o, al menos, nosotros no lo conocemos.

63. 2003, 205.

64. Este era uno de los procedimientos que, junto a la promulgación directa de leyes y a la resolución de los casos particulares que no estuvieran contemplados en el derecho escrito, utilizaron los monarcas del reino de Toledo para ejercer su autoridad en el terreno legislativo (VALVERDE Castro 2000, 227-230). 
otra ley contra todos los que mantuvieran relaciones carnales de carácter homosexual que, con el título De sodomitis, qua debeant ultionis sententia perculi ("De las penas con que han de ser castigados los sodomitas»), fue incluida en el Liber Iudiciorum (L.I. 3.5.7) $)^{65}$.

En la que probablemente haya sido la última disposición sobre la materia que vio la luz en el reino de Toledo ${ }^{66}$, el monarca comienza exponiendo los motivos que le han llevado a legislar sobre la homosexualidad masculina. Afirma:

Ortodoxe fidei ratione conpellimur, legalem censuram inonestis exibere moribus et continentie freno restringere carnis lapsibus inplicatos. Nam tunc potius genti ac patrie nostre clementi pietate consulimus, cum et pravorum funditus scelera extirpare curamus et in male actis vitiorum terminum ponimus. Illius sane facinus detestande libidinis abrogare contendimus, quibus masculi masculos inlicita stupri actione inmundis sordibus maculare non metuunt, tantique se flagitii quoinquinationibus polluunt, quanto ea et divinis adversa cultibus et contraria castitati conspicimus. At vero, licet buiusmodi lapsus et sacre scripture auctoritas et mundane sanctionis proibeat omnino censura, novelle tamen legis neccesse est abrogari sententia, ne, dum emendatio opportuna differtur, peioribus crescere vitiis dinoscatur.

Por razón de la fe verdadera tenemos la obligación de manifestar la censura de la ley contra las costumbres deshonestas y de constreñir con el freno de la continencia a los implicados en los pecados de la carne. Ya que con clemente piedad vigilamos más que nunca por nuestro pueblo y por nuestra patria cuando procuramos extirpar radicalmente los delitos de los malvados y ponemos fin a las malas acciones del vicio. En efecto, intentamos hacer desaparecer aquel delito de detestable concupiscencia en que los hombres no temen deshonrar a otros hombres con un acto ilícito de estupro y con inmunda sordidez, y se contaminan con la infamia de

65. Es necesario aclarar que el Liber no fue una compilación legal estática. Diferentes reyes fueron modificando su contenido, disponiéndose, en la actualidad, de tres versiones diferentes: además de la de Recesvinto, la de Ervigio, que entró en vigor en octubre del 681, y la atribuida a Egica. Como, en su caso, no hay una ley que confirme y feche la revisada versión, se ha cuestionado que Egica hubiese llevado a cabo tal empresa legislativa, pero es indiscutible que leyes suyas fueron incorporadas al Liber, aunque no sea posible precisar cuándo ni por quién con absoluta certeza. Presentan la cuestión, de forma sintética, TorRent 2017b, 41-43; VALVERde CASTRO 2017, 144-145.

66. Es imposible determinar en qué año fue promulgada esta ley de Egica, pero el hecho de que en ella, como tendremos ocasión de constatar algo más adelante, se aluda a un canon conciliar que ya había condenado la homosexualidad durante su reinado induce a pensar que L.I. 3.5.7 se dictó con posterioridad a la reunión del Concilio XVI de Toledo en mayo del 693. 


\section{ROSARIO VALVERDE CASTRO \\ LA CONDENA LEGAL DE LA HOMOSEXUALIDAD MASCULINA \\ EN EL REINO VISIGODO DE TOLEDO}

una torpeza tan grave que la consideramos ofensiva para el culto sagrado, y además de contraria a la castidad. Asimismo, aunque esta clase de faltas ya está totalmente prohibida por la autoridad de la Sagrada Escritura y por las leyes humanas, es necesario que sea extirpada por la sentencia de una nueva ley, porque, mientras se demora la oportuna enmienda, no crezca el mal con vicios peores ${ }^{67}$.

Si en la ley de Chindasvinto se penalizaba la cópula entre hombres por su carácter delictivo y en el canon toledano por constituir una ofensa a Dios, es decir, por ser un acto pecaminoso, ambos aspectos se mezclan ahora en ley de Egica. La homosexualidad que el rey persigue es tanto una acción ilícita (actio inlicita) como un pecado de la carne (lapsus carnis) y es la religión, la ortodoxa fides, lo que le impulsa, es más, le obliga a combatirla. Subyacen, en este enfoque, los principios fundamentales de la teoría político-religiosa que legitimó el poder monárquico en la Hispania goda desde que se produjo la conversión oficial del reino al catolicismo niceno en el Concilio III de Toledo del $589^{68}$. Se inició entonces una completa redefinición de los mecanismos ideológicos en los que se sustentaba el ejercicio del poder real, que no dejó de desarrollarse con el paso del tiempo. Los miembros de la Iglesia hispana transfirieron al monarca godo las ideas que habían legitimado la autoridad del emperador en el imperio romano-cristiano, centradas en la idea de la procedencia divina del poder terrenal, convirtiendo al soberano godo en un rey cristiano. Puesto que creían que el gobierno regio era el medio dispuesto por Dios para que se cumplieran sus designios en la tierra, el monarca tenía la obligación de apartar a sus súbditos del mal y de conducirlos al bien por medio de la ley. Con este tipo de ideología política, no había distinción posible entre cuestiones terrenales y espirituales y, en efecto, ambas esferas vuelven a aparecer mezcladas en el texto de la ley que ahora nos ocupa cuando se afirma que el soberano, "con clemente piedad" (clementi pietate), procura terminar con "los delitos de los malvados" (pravorum scelera) y "las malas acciones del vicio" (in male actis vitiorum). Según afirma Isidoro de Sevilla, a él le correspondía imponer, a través de la disciplina, lo que el sacerdote no pudiera corregir por medio de la predicación de la doctrina ${ }^{69}$.

67. L.I. 3.5.7, líns. 5-15.

68. Para un análisis más detallado de la ideología que legitimó el poder regio y las que hoy llamaríamos atribuciones religiosas del monarca en el reino de Toledo, remitimos a nuestro anterior trabajo, VALVERDE CASTRO 2000, 195-215 y 245-254, donde se incluyen abundantes referencias bibliográficas sobre el tema.

69. Isid., Sent. 3.51.4: [...] intra Ecclesiam potestates necessariae non essent, nisi ut, quod non praevalet sacerdos efficere disciplinam per doctrinae sermonem, potestas hoc imperet per disciplinae terrorem. 
Tenía que legislar, por tanto, para que se cumplieran a rajatabla los preceptos de la moralidad cristiana, pero, al hacerlo, el monarca también estaba ejerciendo sus funciones políticas, porque, como declara Egica en su ley 3.5.7., al perseguir a los homosexuales, está actuando a favor de su gens, de su pueblo, y de su patria, es decir, de su reino. Puesto que las relaciones carnales entre hombres eran concebidas como una grave ofensa a la divinidad, que podía desatar su ira, lo que acarrearía terribles consecuencias para el conjunto de los súbditos, el rey, al condenar la homosexualidad, estaba cumpliendo con la responsabilidad, que hoy definiríamos como política, de proteger a sus súbditos. De ahí que en la ley se defienda, con machacona insistencia, la necesidad de erradicar por completo esas relaciones carnales entre hombres que tan peligrosas resultaban para el futuro del reino. No importa que ya hayan sido prohibidas por las Sagradas Escrituras, como recuerda el propio nombre de sodomitas que, de nuevo, se aplica a quienes mantienen relaciones homosexuales. Tampoco que ya existan mundane sanctionis contra ellas, como la de Chindasvinto. El rey siente la necesidad de volver a abordar la cuestión para evitar males mayores. La pena, en consecuencia, va a ser extremadamente dura y, en efecto, lo que Egica prescribe es lo siguiente:

[...] huius legis edicto decernimus, ut quiscumque amodo vel deinceps, seu de religisis, sive ex laicis, cuinslibet etatis aut generis homo prescripto fuerit scelere quibuscumque indiciis manifeste detectus, mox iubente principe vel quolibet iudice insistente non solum castrationem virium perferat, sed insuper illam in se iacturam excipiat ultionis, quam pro bis causis nuper, in anno videlicet tertio regni nostri, sacerdotalis decreti promulgata sententia evidente prescriptione depromsit.

[...] con la promulgación de esta ley decretamos que de ahora en adelante cualquier hombre, sea religioso o laico, de cualquier edad o linaje, que fuere manifiestamente convicto del delito indicado por cualquier clase de indicios, por orden del príncipe o por mandato de cualquier juez, no sea sólo emasculado inmediatamente, sino que, además, reciba aquel castigo que sobre estas causas decretó con obligación manifiesta la sentencia de un decreto sacerdotal promulgada hace poco, o sea, el tercer año de nuestro reinado ${ }^{70}$.

Constatamos cómo la sentencia condenatoria pone el énfasis en señalar quiénes son sus destinatarios. Se destaca que lo prescrito se aplicará a todos los hombres que mantengan relaciones de carácter homosexual, sin que importe cuál sea su condición, laica o eclesiástica, su edad o su

70. L.I. 3.5.7, líns. 15-21. 
estatus social. Todos los reos quedan completamente equiparados. No hay ninguna diferenciación entre ellos que se tenga en consideración y cabe presuponer que las que existían en las disposiciones anteriores habrían resultado automáticamente anuladas. Aunque se adopta la pena corporal impuesta en la ley 3.5.4., es decir, la emasculación, no hay rastro alguno de la distinción que en ella se hacía entre los que cometían el delito voluntariamente y los que eran forzados a hacerlo, que podían ser absueltos si denunciaban al agresor. La sanción añade, a la extirpación de los órganos genitales prevista en la norma de Chindasvinto, lo establecido en un decretus sacerdotalis que había sido aprobado recientemente, durante su mismo reinado. El canon 3 del Concilio XVI de Toledo es la única norma eclesiástica en la que se condenó la homosexualidad masculina siendo monarca Egica, por lo que no habría ningún motivo para dudar de que se está aludiendo a él si no fuera porque en la ley también se afirma que dicho decretus se promulgó en el tercer año de su reinado. Egica se convirtió en soberano en diciembre del 687 y, en consecuencia, el citado decreto tendría que haber visto la luz en el 690, no en mayo del 693, que es cuando se celebró el mencionado concilio toledano. Para resolver esta discordancia, se han barajado dos posibilidades: que en el 690 se hubiese dictado otra disposición sobre la materia, que no ha pervivido ${ }^{71}$, o que haya un error de cálculo en la nueva ley y que, en realidad, quien la haya redactado estuviese haciendo referencia a ese canon 3, que fue aprobado casi seis años después de que Egica accediera al trono, y no tres, como se dice en el texto ${ }^{72}$. De aceptar esta última opción, que es la única que podemos considerar al no disponer de otra disposición conciliar sobre el tema, cobraría sentido la necesidad que se percibe en la ley 3.5.7 de subrayar a quién va dirigida la sentencia, porque, con su promulgación, Egica estaría terminando con la distinción entre laicos y eclesiásticos que la norma sinodal tenía en cuenta a la hora de fijar la condena por homosexualidad. El objetivo de la nueva ley regia, por lo tanto, sería establecer un mismo tipo de sanción para toda clase de reo, lo que suponía un endurecimiento de la condena para los eclesiásticos, que ahora, además de las sanciones de tipo religioso previstas en el canon, sufrirían los mismos castigos corporales e infamantes que los laicos, es decir, castración, azotes y decalvación. Es el punto de vista que defiende Yolanda García López, para quien quedaba así anulada la «prerrogativa a la integridad física», propia de los obispos, que el canon 3 del Concilio XVI de Toledo

71. Cfr. García Iglesias 1976, 85, siguiendo a Karl Zeumer.

72. Cfr. García López 1997, 310. Ureña Smenjaud [1905] 2003, 390-391, también tiende a decantarse por esta posibilidad, aunque sin descartar por completo la anterior. 
había extendido a los clérigos de rango inferior. Cree, pues, que la ley estaría especialmente dirigida a los hombres de Iglesia, cuya condición de eclesiásticos incrementaba la ofensa a Dios que, en su caso, suponía mantener relaciones homosexuales, porque, con semejantes actos, estaban ensuciando las órdenes sagradas que habían recibido. Siendo ellos impuros, contaminaban los cultos que presidían, volviendo su pecado particularmente odioso para la divinidad ${ }^{73}$.

Dos conclusiones se derivan de esta interpretación de la ley 3.5.7: que debió ser posterior al canon y que la posición de Egica tenía que ser fuerte en el imprecisable momento en que la promulgó, presumiblemente después del 693. Solo así se explicaría que el rey anulara parte de la norma conciliar, en perjuicio de los eclesiásticos. Con este perspectiva, su ley contra la homosexualidad puede ser vista como un indicio de determinación regia, como manifestación del decidido intento de Egica de imponer su voluntad, incluso a una de las instituciones más poderosas del regnum, la Iglesia. Durante la primera parte de su reinado, toda su acción de gobierno estuvo condicionada por la lucha de poder con la facción rival, pero cabe la posibilidad de que la represión de una conjura, la conspiración en la que participó el metropolitano de Toledo, Sisberto, le permitiera desarticular a las fuerzas opositoras e iniciar, en torno al 693, una enérgica política de fortalecimiento regio. Sus disposiciones legales, entre las que se incluye la que condena las prácticas homosexuales, serían un revelador testimonio de ese cambio de escenario político ${ }^{74}$.

Otro de los aspectos que Yolanda García López destaca en L.I. 3.5.7 es el mayor protagonismo que otorga al monarca en el procedimiento judicial. Aunque lo habitual en las normas del código que penalizan delitos contra la inmoralidad, en las que, según la autora, se inspiraron los juristas de Egica, sea que el soberano quede como instancia suprema, que solo actúa en caso de necesidad, excepcionalmente, en su norma contra la homosexualidad, es el propio rey, además de los jueces, el que puede emprender la acción judicial contra los sodomitas ${ }^{75}$, un cambio procesal que parece reflejar un particular interés del monarca en tener las manos libres para actuar contra ellos.

73. García López 1997, 316-319. Para llegar a estas conclusiones argumenta que, al dirigir a los clérigos la parte del proemio donde se afirma que esa falta contra la castidad es tan grave que atenta contra el culto sagrado, Egica vincula su ley con las disposiciones que condenan otras relaciones ilícitas practicadas por los religiosos, unas leyes que destacan «la "especial» incompatibilidad que este tipo de descarríos tienen con las personas comprometidas a Dios".

74. Es el punto de vista defendido por Poveda Arias 2015, 13-46.

75. GarCía López 1997, 311-312. 
4. A modo De Conclusión: motivos de la CONDENA LEGAL

DE LA HOMOSEXUALIDAD MASCULINA POR LA MONARQUÍA VISIGODA

¿Por qué tan decidido empeño regio, como el que acabamos de descubrir durante el reinado de Egica, en erradicar la práctica de la homosexualidad? ¿Qué explica el incremento de la severidad con que se penalizan las relaciones sodomíticas durante su reinado y el afán por destacar su carácter pecaminoso? Creemos que la respuesta está directamente relacionada con la atmósfera, de corte milenarista, que se instaló en la península ibérica en la segunda mitad del siglo $\mathrm{VII}^{76}$. Durante esa centuria, y en buena medida como consecuencia de la expansión por los territorios del Imperio romano oriental primero de los persas y después de los musulmanes, se difundió un pensamiento profundamente pesimista por todo el Mediterráneo, que derivó en la convicción de que la parusía era inminente $^{77}$. El mismo ambiente, cargado de tensión escatológica, se descubre en la península ibérica a partir de los años 40 del siglo vil y las expectativas milenaristas fueron creciendo con el paso del tiempo, de manera que "dans le dernier tiers du VIIe siècle l'idée de fin du monde était ainsi devenue suffisamment proche pur être sentie comme tangible ${ }^{78}$. Tanto la primigenia condena cristiana de la homosexualidad, asociada al nombre de Pablo, como las disposiciones de Justiniano que la penalizaron, habían surgido en contextos históricos cargados de fuertes tensiones escatológicas. Se ha vinculado la severa desaprobación paulina de la búsqueda del placer carnal y, en consecuencia, del sexo entre personas del mismo género con la urgente necesidad de prepararse para el Juicio Final, que se preveía cercano ${ }^{79}$. Así mismo se han relacionado las normas justinianeas contra la homosexualidad con las catástrofes naturales, terremoto y peste, que asolaron Constantinopla durante su reinado ${ }^{80}$. Eran circunstancias

76. En el mismo sentido, se han pronunciado García López 1997, 313-314 y Poveda ARIAs 2015,35 y 46.

77. García Moreno 1997, 249-254, sostiene que «la Cristiandad mediterránea se vio sacudida por un profundo schock de signo escatológico» tras la toma de Jerusalén por los persas en mayo del 614. Que en el 636 la ciudad pasara a manos de los musulmanes y que estos llegaran a asediar Constantinopla en el 673 fueron acontecimientos que no hicieron sino reforzar la creencia en que la hora del fin estaba cerca. Más recientemente, Wickнам [2009] 2014, 330-333, ha establecido la misma relación entre la crisis que se vivió en Oriente en el siglo vir y la difusión de escritos apocalípticos, tanto entre cristianos como entre judíos.

78. Es la conclusión a la que llega MARTIN 2003, 322-329, tras demostrar cómo las inquietudes escatológicas se intensifican en el reino de Toledo en la segunda mitad del siglo VII. Comparte sus ideas Díaz 2008, 28-29.

79. Boswell [1980] 1993, 140; Brundage [1987] 2000, 77-79.

80. Feijóo Morote 2015, 283. 
propicias para que se generasen cosmovisiones de carácter apocalíptico, porque se creía que todo tipo de desastres naturales precederían al fin de los tiempos, y, como hemos tenido ocasión de constatar, si Justiniano legisló contra los homosexuales fue porque había que evitar que pecadores como ellos desataran la ira divina que ya había causado, en el pasado, la destrucción de Sodoma. El mismo temor a la proximidad del fin, casi «tangible» en tiempos de Egica, puede explicar su empeño en terminar, de raíz, con las relaciones homosexuales ${ }^{81}$. Que en las normas para tratar de lograrlo se manifieste que se combaten "semejantes inmundicias» porque impiden el acceso al reino de los cielos y porque se siente la necesidad de conjurar todo acto que pueda desatar la temida venganza divina parece confirmar la vinculación que se dio entre inquietud escatológica y condena de la homosexualidad durante el reinado de Egica. En la misma dirección apunta que fuera entonces cuando triunfó la interpretación homosexual del pecado sodomítico, incuestionable en los textos legales en los que se prohibió la cópula entre hombres por deseo expreso del monarca.

Este tipo de razonamiento no sirve para explicar qué llevó a Chindasvinto a publicar su ley contra las prácticas homosexuales. En ella, no se aprecia ningún tipo de preocupación escatológica, ni hay rastro del carácter pecaminoso que, en tiempos de Egica, se otorgó a la cópula entre hombres. En un reino en el que, desde la conversión a la ortodoxia, el ejercicio del poder regio se legitimaba en la idea del origen divino del poder terrenal, a primera vista, puede sorprender el enfoque, eminentemente profano, de la disposición 3.5.4 en la que Chindasvinto condena la homosexualidad. Pero este monarca, uno de los reyes más enérgicos de la Hispania goda, que dictó medidas persecutorias contra la nobleza y trató de imponer un fuerte centralismo político, también pretendió una laicización de sus acciones gubernativas ${ }^{82}$, que se refleja, a la perfección, en su ley 3.5.4. No es posible, en cambio, saber por qué decidió emprender su innovadora persecución, en el ámbito peninsular, de los hombres que yacieran con sus congéneres. Con anterioridad a él, en el Imperio romano

81. Determinadas circunstancias históricas, particulares de la Hispania goda a finales del siglo vII, principios del VIII, solo podían obrar a favor de la intensificación de la tensión escatológica. Hay que destacar, en este sentido, que los musulmanes ya estuvieran peligrosamente asentados en las cercanas costas del norte de África (GARCía Moreno 2013, 92-122), pero, también, que tanto durante el reinado de su predecesor, Ervigio (680-687), como en el suyo propio, estallaron sendos brotes de peste (Menśndez Bueyes 2013, 62-65), tan virulentos, que incluso el último de ellos pudo inducir a Egica y a su hijo Witiza, ya corregente, a abandonar la sede regia, Toledo, para dirigirse a Córdoba, huyendo de sus efectos (VAlverde CASTRO 2017, 146-148).

82. Cfr. Díaz 2007, 423-425. 
oriental, Justiniano ya había condenado a todos los que mantuvieran relaciones homosexuales, pero, dado que no es posible asegurar si la legislación justineanea se conoció en el regnum Toletanum, tampoco se puede aseverar si fueron sus disposiciones la fuente de inspiración de la normativa de Chindasvinto al respecto.

A pesar de los puntos oscuros que quedan por esclarecer, lo que es indiscutible es que fue en el reino visigodo de Toledo donde se promulgaron, con carácter excepcional en el Occidente postimperial, severas normas contra las relaciones homosexuales y habrá que esperar hasta bien avanzada la Edad Media para que vuelva a legislarse al respecto. Esas disposiciones que condenaron las que fueron consideradas conductas abominables se promulgaron por iniciativa regia, no eclesiástica, como cabría esperar siguiendo los estereotipos existentes sobre la supuesta sempiterna condena cristiana de la homosexualidad. Fueron dos de los reyes que, con mayor determinación, impulsaron políticas de fortalecimiento regio, Chindasvinto y Egica, quienes promovieron la adopción de las medidas que la condenaran, aunque, en realidad, no se penalizaron todas las relaciones carnales entre personas del mismo sexo. Solo se condenó la cópula entre hombres. La posibilidad de que las mujeres se amasen entre ellas ni siquiera fue tomada en consideración. Su invisibilidad, en esta ocasión, les resultó beneficiosa.

\section{FUENTES}

Conc. Elib. = Concilium Eliberritanum, eds. y trads. Vives, José, Martín Martínez, Tomás, Martínez Díez, Gonzalo (1963): Concilios visigóticos e hispano-romanos, Barcelona-Madrid, 1-15.

Isid., Sent. = Isidorus, Sententiae, ed. y trad. Roca Melíe, Ismael (1971): "Los tres libros de las "Sentencias", de San Isidoro. Versión, introducción y notas», en Campos, Julio, Roca, Ismael: Santos Padres españoles II. San Leandro. San Fructuoso. San Isidoro. Reglas monásticas de la España visigoda. Los tres libros de las "Sentencias", Madrid, 211-525.

Iust., Nov. 77 y 141 = Iustinianus, Corpus Iuris Civilis III, Novellae; ed. y trad. Espejo Muriel, Carlos (1991): El deseo negado. Aspectos de la problemática homosexual en la vida monástica (siglos III-VI d. C.), Granada, 189-191 y 229-231.

L.I. = Liber Iudiciorum; eds. y trads. Ramis SerRa, Pedro, Ramis Barceló, Rafael (2015): El libro de los juicios (Liber Iudiciorum), Madrid.

Tol. XVI = Concilium Toletanum XVI, eds. y trads. VIVes, José., MarTíN Martínez, Tomás, Martínez Díez, Gonzalo (1963): Concilios visigóticos e hispano-romanos, Barcelona-Madrid, 482-521. 
6. Bibliografía

Alvarado Planas, Javier (1997): El problema del germanismo en el derecho español. Siglos V-XI, Madrid.

Álvarez Cora, Enrique (1997): "Derecho sexual visigodo», Historia, Instituciones, Documentos, 24, 1-52.

Arce, Javier (2011): Esperando a los árabes. Los visigodos en Hispania (507-711), Madrid.

BAILEY, Derrick Sherwin (1955): Homosexuality and Western christian tradition, London.

BARBIERA, Irene (2012): Memorie sepolte. Tombe e identità nell'Alto Medioevo (secoli $V$-VIII), Roma.

Borrillo, Daniel (2016): «Histoire juridique de l'orientation sexuelle», ENM. Conférence dans le cadre de la formation continue de l'École Nationale de la Magistrature a Paris, Paris, 1-17 [https://hal.archives-ouvertes.fr/ hal-01398557; consultado el 11-I-2019].

Boswell, John ([1980] 1993): Cristianismo, tolerancia sexual y homosexualidad. Los gays en Europa occidental desde el comienzo de la Era Cristiana hasta el siglo XIV, Barcelona.

Brown, Peter ([1988] 1993): El cuerpo y la sociedad. Los cristianos y la renuncia sexual, Barcelona.

Brundage, James ([1987] 2000): La ley, el sexo y la sociedad cristiana en la Europa medieval, México.

Cantarella, Eva ([1988] 1991): Según natura. La bisexualidad en el mundo antiguo, Madrid.

Carrasco Manchado, Ana Isabel (2008): "Entre el delito y el pecado: el pecado contra naturam", en CARrasco Manchado, Ana Isabel, Rábade Obradó, María del Pilar (coords.): Pecar en la Edad Media, Madrid, 113-148.

Codoñer, Carmen (coord.) (2010): La Hispania visigótica y mozárabe. Dos épocas en su literatura, Salamanca.

Crouch, Jace (2010): "The Judicial Punishment of Decalvatio in Visigothic Spain: A Proposed Solution based on Isidore of Seville and the Lex Visigothorum", The Mediterranean Review, 3/1, 59-77.

Díaz, Pablo C. (2003): "Las cárceles en la Hispania visigoda», en Torallas Tovas, Sofía, Pérez Martín, Inmaculada (eds.): Castigo y reclusión en el mundo antiguo, Madrid, 193-207.

Díaz, Pablo C. (2007), "La Hispania visigoda», en Díaz Martínez, Pablo C., Martínez Maza, Clelia, Sanz Huesma, Francisco Javier: Hispania tardoantigua y visigoda, Madrid, 257-637. 
Díaz, Pablo C. (2008): "Los godos como epopeya y la construcción de identidades en la historiografía española", Anales de Historia Antigua, Medieval y Moderna, 40, 25-73.

Díaz, Pablo C., Valverde, Rosario (2007): "Goths confronting Goths: Ostrogothic Political Relation in Hispania», en Barnish, Sam J., MarazzI, Federico (eds.): The Ostrogoths. From the Migration Period to the Sixth Century, San Marino, 353-376.

DíAz y DíAz, Manuel (1976): "Titulaciones regias en la monarquía visigoda», Revista Portuguesa de Historia, 16, 133-141.

Dubreuce, Alain (2005): "Le mariage dans la loi des wisigoths", en Aurell, Martin, Deswarte, Thomas (eds.): Famille, violence et christianisation au Moyen Âge (Mélanges offerts á Michel Rouche), París, 29-56.

Espejo Muriel, Carlos (1991): El deseo negado. Aspectos de la problemática homosexual en la vida monástica (siglos III-VI d. C.), Granada.

Feijóo Morote, Manuel (2015): "Doctrina cristiana, costumbre social y homosexualidad entre la Época Clásica y la Alta Edad Media europea", en $V$ Congreso Interdisciplinar de Jóvenes Historiadores. Amor y sexualidad en la Historia, Salamanca, pp. 269-289.

FérAY, Jean-Claude (1981): "Une histoire critique du mot homosexualité», Arcadie, 325, 11-21.

Foucault, Michel, Sennett, Richard (1981): "Sexuality and Solitude», London Review of Books, 3/9, 3-7.

Gacto Fernández, Enrique (1975): La condición jurídica del cónyuge en el Derecho visigodo y en los fueros de León y Castilla, Sevilla.

Gallego Franco, Henar (2003): «La sexualidad en "Las Etimologías» de San Isidoro de Sevilla: cristianismo y mentalidad social en la Hispania visigoda", Hispania Sacra, 55, 407-431.

Gallego Franco, Henar (2004): «Legislación y sexualidad en la Hispania visigoda", en Jerarquías religiosas y control social en el mundo antiguo. Actas del XXVII Congreso Internacional GIREA-ARYS VIII (Valladolid, 7-9 noviembre, 2002), Valladolid, 611-625.

García Iglesias, Luis (1976): "La edad difícil y la sexualidad adolescente en la España visigoda", HAnt, 6, 79-96.

García López, Yolanda (1997): Estudios críticos y literarios de la "Lex Wisigothorum", Alcalá de Henares.

García Moreno, Luis Agustín (1997): «Expectativas milenaristas y escatológicas en la España tardoantigua (ss. V-VIII)», en Jornadas Internacionales: Los Visigodos y su mundo, Madrid, 247-258.

García Moreno, Luis Agustín (2013): España 702-719. La conquista musulmana, Sevilla.

Gentili, Bruno (1989): Poesia e pubblico nella Grecia antica, Bari. 
Heather, Peter (2004): «Roman Diplomacy and the Gothic Problem: 376418 A. D.", en Giorcelli Bersani, Silvia (a cura di): Romani e Barbari. Incontro e scontro di culture. Atti del Convengo - Bra, 11-13 aprile 2003, Torino, 141-159.

Hedeager, Lotte (1993): "The Creation of Germanic Identity", Mémories du Musée de Préhistoire d'Ile-de-France, 5, 121-131.

IbáÑez AlleR, Juan (1999): «Aproximación a la problemática de la sexualidad en las reglas monásticas masculinas hispanovisigodas: las regulae de San Isidoro y San Fructuoso", en Homenaje al Prof. Montenegro, Valladolid, 759-771.

Jiménez Garnica, Ana María (1995): "La mujer en el mundo visigodo», en Verdejo SÁnchez, María Dolores (coord.): Comportamientos antagónicos de las mujeres en el mundo antiguo, Málaga, 127-160.

Joye, Sylvie (2012): «Fabrique d'une loi, fabrique d'un peuple», en Beaulande-Barraud, Véronique, Claustre, Julie, Marmursztejn, Eisa: la fabrique de la norme. Lieux et modes de production des normes au Moyen Âge et à l'époque moderne, Rennes, 91-108.

KelLY, Michael J. (2017): «Recceswinth's Liber Iudiciorum: History, Narrative and Meaning", VgS, 1, 110-130.

KING, Paul D. ([1972] 1981): Derecho y sociedad en el reino visigodo, Madrid.

KuEfLer, Mathew (2019): "The formation of the homosexual subject in Late Roman Antiquity", en Joye, Sylvie, La Rocca, María Cristina, Gioanni, Stéphane (eds.): La construction sociale du sujet exclu (IVe-XIe siècle), Turnhout, 227-240.

Lear, Floyd S. (1951): «The Public Law of the Visigothic Code», Speculum, 26/1, 1-23.

Liebeschuetz, John Hugo Wolfgang Gideon (1992): «Alaric's Goths: Nation or Army?», en DrinKWater, John, Elton, Hugh (eds.): Fifth-Century Gaul: A Crisis of Identity?, Cambridge, 75-83.

MarTin, Céline (2003): La géographie du poivoir dans l'Espagne visigothique. Villneuve d'Ascq.

Martin, Céline (2011): "Le Liber Iudiciorum et ses différentes versions», Mélanges de la Casa de Vélazquez. Nouvelle série, 41/2, 17-34.

MarTin, Céline (2015): «Ne inter coniuges diuortium fiat,, en JÉGOU, Laurent, Joye, Sylvie, Lienhard, Thomas, Schneider, Jens (eds.): Splendor Reginae: Passions, genre et famille. Mélanges en l'honeur de Régine Le Jan, Turhout, 93-100.

MenÉNDeZ BueYes, Luis Ramón (2013): Medicina, enfermedad y muerte en la España tardoantigua. Un acercamiento bistórico a las patologias de las poblaciones de la época tardorromana e hispanovisigoda (siglos IV-VIII), Salamanca. 
Morales Arrizabalaga, Jesús (1995): Ley, jurisprudencia y derecho en Hispania romana y visigoda, Zaragoza.

Отеro, Alfonso (1959): "Liber Iudiciorum 3,1,5 (En tema de la dote y donatio propter nuptias)", AHDE, 29, 545-555.

Petit, Carlos (2001): Iustitia Gothica. Historia Social y Teología del Proceso en la Lex Visigothorum, Huelva.

Petit, Carlos (2007): "Derecho visigodo del siglo viI. Un ensayo de síntesis e interpretación", en Hispania Gothorum. San Ildefonso y el Reino Visigodo de Toledo, Toledo, 75-85.

Poveda Arias, Pablo (2015): "Relectura de la supuesta crisis del fin del reino visigodo de Toledo: una aproximación al reinado de Egica a través de sus fuentes legales", AHDE, 85, 13-46.

Ramis Barceló, Rafael (2015): "Estudio preliminar», en Ramis SERra, Pedro, Ramis Barceló, Rafael: El libro de los juicios (Liber Iudiciorum), Madrid, 11-30.

SAntinelui, Emmanuelle (2003): Des femmes épolorées? Les veuves dans la société aristocratique du haut Moyen Âge, París.

TORRent, Armando (2017a): "La represión del adulterium en las leyes romano-bárbaras y particularmente en la legislación hispano-visigótica", Teoria e Storia del Diritto Privato, 10, 1-75.

Torrent, Armando (2017b): «Una aproximación a la legislación visigótica hispana. La imitatio imperii, RIDROM, 18, 1-63.

Ureña y Smenjaud, Rafael ([1905] 2003): La legislación gótico-hispana (Leges antiquiores-Liber Iudiciorum). Estudio crítico, Pamplona, 2003.

Valverde Castro, Rosario (2000): Ideología, simbolismo y ejercicio del poder real en la monarquía visigoda: un proceso de cambio, Salamanca.

Valverde Castro, Rosario (2003): "La reina viuda en el derecho visigodo: religionis habitum adsumat", AHDE, 73, 389-406.

Valverde Castro, Rosario (2017): Los viajes de los reyes visigodos de Toledo (531-711), Madrid.

Veyne, Paul (1982): "L'homosexualité à Rome», en Sexualités occidentales. Contribution à l'histoire et à la sociologie de la sexualité. Communications, 35, 26-33.

Wemple, Suzanne F. (1999): "Les traditions romaine, germanique et chrétienne», en Klapisch-Zuber, Christiane (ed.): Histoire des femmes en Occident. 2. Le Moyen Âge, Paris, 185-216.

Wickham, Chris ([2005] 2008): Una Historia nueva de la Alta Edad Media. Europa y el mundo mediterráneo, 400-800, Barcelona.

Wickнам, Chris ([2009] 2014): El legado de Roma. Una historia de Europa de 400 a 1000, Barcelona.

Williams, Craig A. (1999): Roman Homosexuality. Ideologies of Masculinity in Classical Antiquity, New York, Oxford. 
